\title{
In Vitro Efficacy of Cyclosporine A and Various Antiseptics and Antiviral Drugs on Adenovirus Genotype 8, a Common Cause of Epidemic Keratoconjunctivitis
}

\section{Aynura Sariyeva Aydamirov ( $\square$ aynuresariyeva91@gmail.com )}

Adana City Training and Research Hospital https://orcid.org/0000-0003-2916-0932

Ibrahim Inan Harbiyeli

Cukurova University, School of Medicine, Department of Ophthalmology

Gokhan Ozturk

Cukurova University, School of Medicine, Department of Microbiology, Division of Virology

Fugen Yarkin

Cukurova Universty, School of Medicine, Department of Microbiology, Division of Virology

Elif Erdem

Cukurova University, School of Medicine, Department of Ophthalmology

Meltem Yagmur

Cukurova University, School of Medicine, Department of Ophthalmology

\section{Research Article}

Keywords: Adenovirus genotype 8, chlorhexidine, cidofovir, cyclosporine A, ganciclovir, povidone iodine.

Posted Date: January 5th, 2022

DOI: https://doi.org/10.21203/rs.3.rs-1189810/v1

License: (c) (i) This work is licensed under a Creative Commons Attribution 4.0 International License.

Read Full License 


\section{Abstract}

Purpose: To evaluate the in vitro efficacy of cidofovir, ganciclovir, povidone iodine, chlorhexidine, and cyclosporine A on adenovirus genotype 8

Methods: Conjunctival samples were collected from patients with adenoviral conjunctivitis and cultured in A549 cells. Adenovirus diagnosis was confirmed by RT-PCR. For each drug, the $50 \%$ cytotoxic concentration (CCQQ) was determined. Subsequently, the antiviral activity was tested at concentrations below CCQU, and the $50 \%$ inhibitor concentration (ICQX) of drugs was determined.

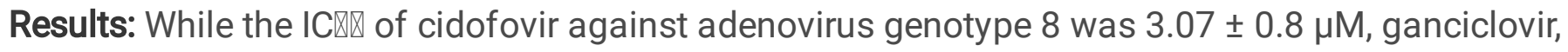
povidone iodine, chlorhexidine, and cyclosporine A were not found to be effective against adenovirus genotype 8 at concentrations below the CCQ value.

Conclusions: Cidofovir was found effective and the ICQX value was within the ranges in the literature. Ganciclovir and cyclosporine A were found to be ineffective at doses below the cytotoxic dose, povidone iodine and chlorhexidine were found to be highly cytotoxic.

\section{Introduction}

Adenoviruses are viruses that contain non-enveloped, double-stranded deoxyribonucleic acid (DNA) in an icosahedral capsid. More than 60 types of adenoviruses divided into seven subgroups (A-G) have thus far been described [1]. Adenoviruses can cause epidemic keratoconjunctivitis, pharyngoconjunctival fever, and nonspecific conjunctivitis. Epidemic keratoconjunctivitis progresses more severely and is more contagious than the other two conditions. Corneal epithelial defects, conjunctival membranes, and pseudomembranes may occur in the early stages of infections. In the advanced stages, corneal subepithelial infiltrates, irregular astigmatism, decreased vision, symblepharon formation, and cicatricial entropion can be seen $[2,3]$. Epidemic keratoconjunctivitis is usually caused by types 8,19 , and 37 , which are included in subgroup $D[4,5]$. Type 8 is the most important and common cause of this condition worldwide [6].

There is no approved or specific treatment for adenovirus. Supportive treatment involves artificial tears and cold compresses. Although the disease is usually self-limiting, visual impairment may develop due to secondary corneal lesions in some cases.

Many studies have evaluated the efficacy of various antiviral and antiseptic agents against adenoviruses [7-10]. Cidofovir and ganciclovir are the leading antiviral agents, and their efficacy against adenoviruses has been studied. Cidofovir is a nucleotide analogue, whereas ganciclovir is a nucleoside analogue, and both agents show virustatic effects by inhibiting the viral DNA polymerase enzyme. Both agents have a broad spectrum of effects on DNA viruses. Although the effect of cidofovir and ganciclovir against adenovirus has been demonstrated in vitro, in vivo and clinical studies have reported conflicting results [8, $11-13]$. 
In addition to antiviral drugs, the in vitro and in vivo efficacies of various antiseptic agents against adenovirus have been examined in many studies [9, 14-16]. Povidone iodine (PVP-I) and chlorhexidine (CHX) are broad-spectrum antiseptics used to perform skin antisepsis and to disinfect medical devices before surgical procedures. Bacteria, bacterial spores, fungi, and viruses have a spectrum of effects [17, 18]. In vitro studies have shown that PVP-I is highly effective in the elimination of adenovirus and can reduce the viral load in tears, as well as the risk of virus spread [14]. Low concentrations of CHX are used in the treatment of bacterial, fungal, and parasitic keratitis $[19,20]$. The antiviral activity of this agent has been shown against herpes simplex virus (HSV), human immunodeficiency virus (HIV), cytomegalovirus $(\mathrm{CMV})$, and parainfluenza virus, but its effectiveness against adenovirus has not been determined [10].

Cyclosporine-A (CSA) is an immunosuppressive agent that acts through calcineurin inhibition and is used to prevent rejection following tissue and organ transplantations [21]. Its topical forms are used in the long-term treatment of many ocular diseases of inflammatory origin (vernal keratoconjunctivitis, dry eye, etc.) because of its low side effect profile [22]. It is also used effectively in the treatment of corneal subepithelial deposits that occur after adenoviral keratoconjunctivitis [22]. In recent years, the possible antiviral effects of CSA have been emphasized. It has been reported that this drug can inhibit virus replication through action on interferons (IFN) and can show antiviral activity against various viruses [23]. Its antiviral activity against HSV, hepatitis $\mathrm{C}$ virus $(\mathrm{HCV})$, and rotavirus have further been demonstrated.

This study aimed to evaluate the in vitro efficacy of various agents against adenovirus genotype 8 . In this study, cidofovir and ganciclovir were used because of their broad-spectrum antiviral effect on DNA viruses; $\mathrm{CHX}$ and PVP-I were chosen because they have a wide spectrum of antimicrobial actions and have important usage advantages owing to their low cost and easy accessibility. CSA was selected because its antiviral efficacy has never been studied for adenoviruses and its safety profile in ocular use is well known.

\section{Materials And Methods}

The study design adhered to the tenets of the Declaration of Helsinki and was approved by the Cukurova University Medical Faculty Ethics Committee*. Samples were taken from the conjunctiva of patients clinically diagnosed with adenoviral conjunctivitis by using flocked swabs (Copan Diagnostics Inc., Italy) in the Department of Ophthalmology, Faculty of Medicine, Cukurova University. Samples were placed in $15 \mathrm{ml}$ falcon tubes containing $1 \mathrm{ml}$ of viral transport medium (antibiotic-antimycotic-supported Dulbecco's Modified Eagle Medium [DMEM]) and sent to the Medical Virology Laboratory. Continuous cell line A549 cells were used for the isolation of adenoviruses. For cell culture of clinical samples, 24-well plates ( ${ }^{\mathrm{TM}} \mathrm{BioLite}$, Thermo Fisher Scientific, USA) were used. The medium in one well of the plate was removed without damaging the cell layer, and $500 \mu \mathrm{l}$ of the supernatant from the centrifuged clinical sample was inoculated into the well. The plate was incubated for $1 \mathrm{~h}$ at $37^{\circ} \mathrm{C}$ and $5 \% \mathrm{CO}_{2}$ to allow virus attachment to the cells. Subsequently, DMEM (Gibco, Thermo Fisher Scientific, USA) with fetal bovine serum (FBS) $2 \%$ at final concentration (PAN Biotech, Germany) was added to the wells and incubated for 7 days. The cytopathic effect (CPE) was monitored daily. When CPE was detected and DNA was extracted 
(Bosphore Viral DNA Detection Kit Anatolia Geneworks, Turkey), adenovirus was confirmed by adenovirus real-time polymerase chain reaction (RT-PCR, PCR Bosphore Adenovirus Detection Kit v1, Geneworks Anatolia, Turkey). The infectivity of the adenovirus isolate was determined using the tissue culture infectious dose $50 \%\left(\mathrm{TCID}_{50}\right)$ method. The same adenovirus isolate was used in all antiviral tests.

The typing process of the adenovirus isolate used in the study was performed by PCR amplification of a segment of the hexon gene fragment. In the first stage of the PCR process, a 1004 bp PCR product formation was investigated using the primers AdTU7 (position 20,734-20,753 5'-

GCCACCTTCTTCCCCATGGC-3') and AdTU4 (position 21,718-21,737 5'-GTAGCGTTGCCGGCCGAGAA-3'). In the second phase, $956 \mathrm{bp}$ PCR product formation was investigated using primers AdnU-S (position 20,743-20,762 5'-TTCCCCATGGCCCACAACAC-3') and AdnU-A (position 21,679-21,698 5'GCCTCGATGACGCCGCGGTG-3'). PCR mix total volume was $50 \mu$ and contained $200 \mu \mathrm{M}$ dNTP (dNTP Set, \# R0181, Thermo Scientific, USA), 1.25 U Taq DNA polymerase, $1.5 \mathrm{mM} \mathrm{MgCl}_{2}, 1$ X PCR buffer (D4545, Sigma, USA) and $0.5 \mu \mathrm{M}$ of each primer. The first stage of the PCR process was performed on 5 $\mu \mathrm{l}$ of viral nucleic acid extract obtained from the clinical isolate (Viral DNA Extraction Spin Kit, Anatolia Geneworks, Turkey). In the second stage, $2 \mu$ l of the product of the first amplification stage was used. The thermal cycle for the PCR process was set as follows: initial denaturation at $94^{\circ} \mathrm{C}$ for $10 \mathrm{~min}$, then 36 cycles of denaturation at $94^{\circ} \mathrm{C}$ for $1 \mathrm{~min}$, binding at $50^{\circ} \mathrm{C}$ for $1 \mathrm{~min}$, elongation at $72^{\circ} \mathrm{C}$ for $2 \mathrm{~min}$, and final extension at $72^{\circ} \mathrm{C}$ for $7 \mathrm{~min}$. The MJ Mini Thermal Cycler device (Bio-Rad, PCR) was used for amplification. A PCR Mix with the same content and the same thermal cycle were used in both PCR steps. After nested-PCR amplification, $10 \mu \mathrm{l}$ of the PCR product was subjected to electrophoresis using a $2 \%$ agarose gel containing $5 \mu \mathrm{g} / \mathrm{ml}$ ethidium bromide. The product of the second PCR stage of the positive clinical isolate was purified using the HighPrep ${ }^{T M}$ PCR Clean-up System (AC-60005, MAGBIO, USA) purification kit, according to the manufacturer's instructions. In the Macrogen Netherlands laboratory, DNA sequence analysis was performed using the ABI 3730XL Sanger Sequence instrument (Applied Biosystems, Foster City, CA) and the BigDye Terminator v3.1 Cycle sequence Kit (Applied Biosystems).

The effectiveness of the antiviral agents cidofovir and ganciclovir, the antiseptics PVP-I and CHX, and the immunosuppressive drug CSA against adenovirus were investigated in vitro. To determine the toxicity of antiviral agents to the cell, a cytotoxicity test was performed using colorimetric methods, and the antiviral activity was evaluated. The antiviral efficacy test was performed at concentrations lower than the $50 \%$ cytotoxic concentration $\left(\mathrm{CC}_{50}\right)$, as determined by the cytotoxicity tests, and the $50 \%$ inhibitory concentration $\left(\mathrm{IC}_{50}\right)$ was determined.

Cell culture was performed under sterile conditions using a biological safety class II vertical laminar flow cabinet. A549 cells (in $25 \mathrm{~cm}^{2}$ or $75 \mathrm{~cm}^{2}$ flasks; Thermo Fisher Scientific) were cultured by incubation in DMEM (4.5 g/L d-glucose, $4.0 \mathrm{mM}$ l-glutamine, and sodium pyruvate) containing $10 \% \mathrm{FBS}$ at $37^{\circ} \mathrm{C}$ in $5 \%$ $\mathrm{CO}_{2}$. To prevent contamination, the medium was supplemented with an antibiotic-antimycotic solution (BIOWEST, France), according to the manufacturer's instructions. For subculturing, the cells were trypsinized with trypsin-ethylenediamine tetra-acetic acid (trypsin-EDTA) solution prior to passaging. The 
virus titre used to determine antiviral activity according to the Spearman-Karber method was determined to be $100 \mathrm{TCID}_{50}$.

Cidofovir (Sigma), ganciclovir (Acros Organics, Thermo Fisher Scientific), PVP-I (Sigma), chlorhexidine digluconate $20 \%$ (Sigma), and CSA (Acros Organics) were prepared immediately before testing with $2 \%$ FBS DMEM. To determine drug cytotoxicity and antiviral activity, 96-well plates (Thermo Fisher Scientific) were used. For cytotoxicity testing, cidofovir was prepared at 1000, 500, 400, 200, 100, 50, 20, 10, and 5 $\mu \mathrm{M}$ dilutions. The concentrations studied for ganciclovir were $12 \mathrm{mM}, 9 \mathrm{mM}, 6 \mathrm{mM}, 4 \mathrm{mM}, 2 \mathrm{mM}, 1 \mathrm{mM}$, 0.8, 0.4 mM, and 0.2 mM. PVP-I was prepared in concentrations of $5 \%, 2 \%, 1 \%, 0.5 \%, 0.2 \%, 0.1 \%, 0.05 \%$, $0.02 \%$, and $0.001 \%$. For $\mathrm{CHX}$, dilutions of $0.08 \%, 0.04 \%, 0.02 \%, 0.01 \%, 0.005 \%, 0.002 \%, 0.001 \%, 0.0005 \%$, and $0.0002 \%$ were used. CSA was prepared at concentrations of $100 \mu \mathrm{M}, 50 \mu \mathrm{M}, 25 \mu \mathrm{M}, 10 \mu \mathrm{M}, 5 \mu \mathrm{M}, 2.5$ $\mu \mathrm{M}, 1 \mu \mathrm{M}, 0.5 \mu \mathrm{M}$, and $0.2 \mu \mathrm{M}$. For each dilution of the drugs, $200 \mu \mathrm{l}$ was distributed into four wells of a 96-well plate. Medium was added to the control wells. The plates were incubated for 6 days at $37^{\circ} \mathrm{C}$ in a $5 \% \mathrm{CO}_{2}$ environment. $\mathrm{CPE}$ was evaluated microscopically every day, and at the end of the sixth day, 3(4,5-dimethylthiazol-2-yl)-5-(3-carboxymethoxyphenyl)-2-(4-sulfophenyl)-2H-tetrazolium test (MTS) (CellTiter 96® AQueous One Solution Cell Proliferation Assay, Promega, PCR) was performed to determine cell viability. After incubation, washing was performed three times. Absorbance values were determined by measuring the amount of formazan in the wells at an optical density of $570 \mathrm{~nm}$.

The $\mathrm{CC}_{50}$ value of each drug was calculated using the absorbance values determined using GraphPad Prism 8. The cytotoxicity test was repeated three times for each drug, and the mean $\mathrm{CC}_{50}$ value was determined. The concentrations used in the antiviral activity test were below the $\mathrm{CC}_{50}$ value calculated from the cytotoxicity test. The concentrations studied for cidofovir were 200, 100, 50, 20, 10, 5, 2.5, 1, and $0.5 \mu \mathrm{M}$. The doses for ganciclovir were $2,1,0.8,0.4$, and $0.2 \mathrm{mM}$. For PVP-I, the concentrations were $0.5 \%$, $0.2 \%, 0.1 \%, 0.05 \%, 0.02 \%, 0.01 \%, 0.005 \%, 0.002 \%$, and $0.001 \%$. Doses for $\mathrm{CHX}$ were $0.001 \%, 0.0005 \%$, $0.0002 \%, 0.0001 \%, 0.00005 \%$, and $0.00002 \%$. For CSA, the concentrations were $10 \mu \mathrm{M}, 5 \mu \mathrm{M}, 2 \mu \mathrm{M}, 1 \mu \mathrm{M}$, $0.5 \mu \mathrm{M}, 0.2 \mu \mathrm{M}, 0.1 \mu \mathrm{M}$, and $0.05 \mu \mathrm{M}$. For each concentration in the antiviral efficacy test, $100 \mu$ of virus solution was inoculated into the cells at $80-90 \%$ confluency in four wells of a 96 -well plate. Plates were incubated for $2 \mathrm{~h}$ at $37^{\circ} \mathrm{C}$ in a humid $5 \% \mathrm{CO}_{2}$ environment. After the incubation period, $100 \mu \mathrm{l}$ of virus solution was removed, and $200 \mu \mathrm{l}$ of the drug to be studied was added. The presence of CPE on the plates was examined daily using a microscope. At the end of the incubation period, 3-(4,5dimethylthiazol-2-yl)-2,5-diphenyl tetrazolium bromide (MTT) test was performed, and the absorbance values were determined by measuring the optical density at $570 \mathrm{~nm}$. The $\mathrm{IC}_{50}$ value of each drug was calculated using the GraphPad Prism 8 program, with the absorbance values obtained. The antiviral test was repeated three times for each drug, and the mean $\mathrm{IC}_{50}$ value was subsequently determined.

\section{Results}

As a result of DNA sequence analysis, the clinical isolate was determined to be adenovirus genotype 8 . The $\mathrm{CC}_{50}$ values of drugs in the A549 cell culture were as follows: $564 \pm 26 \mu \mathrm{M}$ for cidofovir (Figure 1), 
$2.209 \pm 0.319 \mathrm{mM}$ for ganciclovir (Figure 2), $0.54 \pm 0.06 \%$ for PVP-I (Figure 3), $0.00058 \pm 0.0002 \%$ for $\mathrm{CHX}$ (Figure 4), and $6.11 \pm 0.23 \mu \mathrm{M}$ for CSA (Figure 5). The same adenovirus clinical isolate was used for all drugs in the antiviral tests. The $\mathrm{IC}_{50}$ value of cidofovir was $3.07 \pm 0.8 \mu \mathrm{M}$ against adenovirus genotype 8 (Figure 6). Ganciclovir, PVP-I, CHX, and CSA were not found to be effective against adenovirus genotype 8 at concentrations below the $\mathrm{CC}_{50}$ value. The $\mathrm{CC}_{50}$ and $\mathrm{IC}_{50}$ values of these agents are summarized in Table 1.

Table 1: The calculated $50 \%$ cytotoxic concentration and $50 \%$ inhibitory concentration of antiviral agents in A549 cells against adenovirus genotype 8

\begin{tabular}{|lll|}
\hline \multicolumn{1}{|c|}{$\mathrm{CC}_{50}$} & $\mathrm{IC}_{50}$ \\
\hline Cidofovir & $564 \pm 26 \mu \mathrm{M}$ & $3.07 \pm 0.8 \mu \mathrm{M}$ \\
\hline Ganciclovir & $2.209 \pm 0.319 \mathrm{Mm}$ & No effect \\
\hline PVP-I & $\% 0.54 \pm 0.06$ & No effect \\
\hline CHX & $\% 0.000589 \pm 0.0002$ & No effect \\
\hline CSA & $6.11 \pm 0.2 \mu \mathrm{M}$ & No effect \\
\hline
\end{tabular}

(PVP-I: povidone iodine, $\mathrm{CHX}$ : chlorhexidine, $\mathrm{CSA}$ : cyclosporine $\mathrm{A}, \mathrm{CC}_{50}: 50 \%$ cytotoxic concentration, $\mathrm{IC}_{50}$ : $50 \%$ inhibitory concentration, No effect: no effect was seen below the cytotoxic concentration)

\section{Discussion}

There is currently no clinically proven treatment option for adenovirus-associated ocular infections, and treatment therefore generally consists of supportive therapy. Therefore, disease-related morbidity and sequelae cannot be prevented, while viral spread continues rapidly because the titre of the virus in the patient cannot be reduced. For these reasons, studies aimed at finding a specific agent for the treatment of adenoviral keratoconjunctivitis are important. In this study, we aimed to evaluate the in vitro efficacy of some agents that are likely to show antiviral activity against adenoviruses. In our study, cidofovir was found to be effective against adenovirus in vitro without unacceptable toxicity, while CHX and PVP-I were found to be highly cytotoxic to A549 cells.

Cidofovir is an important antiviral drug because of its broad spectrum of effects on DNA viruses. Baba et al. reported that cidofovir and ganciclovir showed inhibitory effects in vitro on eight different adenovirus serotypes (serotypes 1-8) produced in human embryonic fibroblast culture [7]. The mean $\mathrm{IC}_{50}$ values for the eight serotypes were 1.1 and $4.1 \mu \mathrm{g} / \mathrm{ml}$ for cidofovir and ganciclovir, respectively. $I_{50}$ value for type 8 was 1 and $2.8 \mu \mathrm{g} / \mathrm{ml}$ for cidofovir and ganciclovir, respectively, while cidofovir was found to be more effective than ganciclovir [7]. De Olivire et al. studied four different adenovirus types (Type 5 McEwen, type 5 WT, type 8, and 14) in A549 cell culture [24]. The mean $\mathrm{IC}_{50}$ value for cidofovir in the 4 groups was $6.7 \mu \mathrm{g} / \mathrm{ml}$ (range $4.7-9.5 \mu \mathrm{g} / \mathrm{ml}$ ). In this study, the $\mathrm{IC}_{50}$ value for adenovirus type 8 was $4.7 \mu \mathrm{g} / \mathrm{ml}$ [24]. In our study, cidofovir was found to be effective against adenovirus type 8 in vitro. In various studies, the detected $\mathrm{IC}_{50}$ values of cidofovir for adenovirus type 8 ranged from 0.47 to $4.7 \mu \mathrm{g} / \mathrm{ml}[24,25]$. This 
difference may be due to the use of different cell cultures in each study. Adenovirus shows tropism towards epithelial cells, and in vitro studies of adenoviruses have shown that the most successful results can be obtained with A549 cells, which contain epithelial-like cells derived from human lung cancer tissue $[26,27]$. For this reason, A549 cell culture was used in our study, and the ICQV value was found to be 3.07 $\pm 0.82 \mu \mathrm{M}$. This value is within the concentration ranges reported in similar studies and, thus, is supported by the literature.

Ganciclovir is another antiviral whose efficacy against adenovirus has been investigated $[7,11,12]$. This drug is phosphorylated by viral thymidine kinase and acts by inhibiting viral DNA polymerase. Trousdale et al. investigated the efficacy of ganciclovir in vitro for adenovirus types 5 and 8 in A549 cell culture [12]. The authors found $\mathrm{IC}_{50}$ values of 47 and $26 \mu \mathrm{M}$ for serotypes 5 and 8, respectively, and they showed the effectiveness of the drug against the virus [12]. Subsequently, they induced experimental conjunctivitis with type 5 in mice and applied topical ganciclovir at concentrations of $3 \%, 1 \%$, and $0.3 \%$ for 21 days. The authors observed that the titre of virus and clinical findings were at the lowest level at $3 \%$ concentration, but they could not detect a significant difference between the groups in their study [12]. Yabiku et al. topically applied $0.15 \%$ ganciclovir to 19 patients with adenoviral conjunctivitis [13]. They compared these patients with a control group of 14 patients with adenoviral conjunctivitis who received artificial tears. Although the authors reported that the improvement in clinical findings was faster in the treatment group, they stated that there was no significant difference between the groups [13]. Ganciclovir was found to be ineffective at concentrations below the cytotoxic concentration in our study. Ganciclovir acts by inhibiting viral thymidine kinase, and it has been emphasized that the limited effect of ganciclovir against adenovirus can be explained by the low viral thymidine kinase activity in these viruses (inducing ganciclovir resistance) [28]. In our study, we thought that the lack of activity below the cytotoxic concentration against type 8 could also be explained by ganciclovir resistance.

PVP-I is a broad-spectrum antimicrobial. In ocular infections of adenovirus, irrigation with a concentration of $5 \%$ of this agent in adults and $2.5 \%$ in children is frequently applied in clinical practice to reduce the titre of virus on the conjunctiva $[15,29]$. Monnerat et al. isolated adenovirus type 8 in A549 cell culture and evaluated the efficacy of diluted PVP-I against the levels of extracellular and intracellular viruses [14]. They demonstrated that PVP-I $(0.8 \%)$ completely extinguished the infectivity of free adenovirus after an exposure time of $10 \mathrm{~min}$, but was less effective against intracellular adenoviruses. Therefore, the authors suggested that in the early period of disease, a $0.8 \%$ concentration of the drug could prevent viral transmission by inhibiting the virus in the tears, but this treatment would not be sufficiently effective in the late period [14]. In addition, they stated that the non-cytotoxic concentration was $0.04 \%$ for the cells in the culture in their study. In our study, we aimed to investigate the efficacy of PVP-I, which is an easily accessible and frequently used antiseptic in clinical practice. We observed that this agent did not show an inhibitory effect against the virus inside the cell at concentrations below the cytotoxic values. In a study by Monnerat et al., the concentration required to inhibit the extracellular virus was found to be much higher than the toxic value in cell culture [14]. Similarly, in our study, we observed that PVP-I exerts a cytotoxic effect on cell culture, even at very low concentrations. Therefore, the effectiveness of this 
agent in cell culture cannot be determined. On the other hand, in a study investigating the clinical effect of PVP-I, Tunay et al. showed that PVP-I at a concentration of $2.5 \%$ was effective in infants with adenoviral conjunctivitis [29]. The effect of PVP-I on extracellular viruses in the early stages of the disease may have a clinically important role. The high cytotoxic effect of this agent makes it difficult to demonstrate possible intracellular activity in vitro. Further in vitro and in vivo studies are needed to study the effectiveness of PVP-I against adenovirus.

$\mathrm{CHX}$ is a broad-spectrum antimicrobial that is more effective against enveloped viruses than nonenveloped viruses [9]. In a study by Wood et al., adenovirus type 25 was isolated in HeLa cells, and CHX at a concentration of $0.1125 \%$ was observed to be toxic to cells [30]. CHX has been found to be ineffective against non-enveloped viruses, including adenoviruses, when applied below the cytotoxic concentration, but is effective against enveloped viruses [30]. Bailey et al. investigated the efficacy of $\mathrm{CHX}$ against enveloped herpes virus and non-enveloped poliovirus and adenovirus type 2 in an in vitro cell culture study [10]. The authors isolated adenovirus in Hep2 cell culture and emphasized that it is difficult to evaluate the effect of $\mathrm{CHX}$ on the virus inside the cell because of its apparent cytotoxic effects. They stated that $\mathrm{CHX}$ is effective against herpes virus (enveloped) in vitro at values below the toxic concentrations and ineffective against poliovirus and adenovirus (non-enveloped) [10]. On the other hand, Springthorpe et al. studied the in vitro effects of various disinfectants against rotavirus, which is a nonenveloped virus similar to adenovirus. They demonstrated the antiviral effect of $\mathrm{CHX}$ and emphasized that its addition to hand antiseptics may partially help to prevent nosocomial transmission of rotavirus [31]. In our study, similar to PVP-I, CHX was found to be quite cytotoxic, even at low concentrations. The finding that $\mathrm{CHX}$ is ineffective against the virus at concentrations below the cytotoxic dose supports the results of Bailey and Wood $[10,26]$. We thought that the problem of cytotoxicity of PVP-I and CHX even at low doses could be overcome by using different cell culture types (e.g., corneal cell culture).

CSA is a strong immunosuppressor and an important option in the long-term treatment of corneal subepithelial deposits to avoid steroid side effects. It has been shown that this drug increases the induction of mediators in IFN production and suppresses the inhibition of mediators. Thus, CSA increases the amount of IFN and has antiviral effects [21]. Shen et al. demonstrated the antiviral efficacy of CSA against rotavirus, a non-enveloped virus such as adenovirus, in in vitro cell culture and in vivo animal models [21]. With CSA below the cytotoxic dose $(<16 \mu \mathrm{g} / \mathrm{ml})$, the reduction was detected in proteins, antigens, and RNA of the virus by direct immunofluorescence and real-time PCR tests in both intracellular and extracellular areas. The researchers demonstrated that IFN- $\beta$ production increases after addition of CSA [21]. Vahlne et al. investigated the in vitro efficacy of CSA against HSV [32]. The inhibitory activity $\left(\mathrm{IC}_{50}=1.3 \mu \mathrm{g} / \mathrm{ml}\right)$ was detected at non-cytotoxic concentrations $(1,5,10,25,50$, and $100 \mu \mathrm{g} / \mathrm{ml})$ [32]. In our study, we observed that CSA had no inhibitory effect on adenovirus at concentrations below the cytotoxic concentration $\left(\mathrm{CC}_{50}: 6.11 \pm 0.23 \mu \mathrm{M}\right)$. We thought that this result may be related to the $\mathrm{E} 1 \mathrm{~A}$ protein, which is one of the structural proteins of adenoviruses and reduces the effect of IFNs [33]. The E1A protein has been shown to suppress the IFN signaling pathway, block IFN-induced transcription mechanisms, and reduce the antiviral effect created by IFN [33]. We thought that the above-mentioned 
mechanisms could explain the ineffectiveness of CSA, which shows IFN-mediated antiviral activity against adenovirus.

In our study, we set out with the theory that using a drug used to prevent sequelae symptoms in the late period of infection with its antiviral effect at an earlier stage may be advantageous to treatment. We aimed to examine the antiviral effect of CSA on adenovirus by establishing the hypothesis that an antiviral drug with a well-known topical side effect profile could be used safely in treatment and could more effectively prevent the development of sequela signs. To the best of our knowledge, our study is the first to evaluate the in vitro efficacy of CSA against adenoviruses. Although CSA had no inhibitory effect on adenovirus at values below the cytotoxic concentration in our study, we believe that our study will guide similar studies in the future.

Since adenoviral conjunctivitis is a major cause of infectious conjunctivitis, it is an important public health issue. In vitro studies for treatment are essential, as they will guide clinical trials. In this study, we determined that cidofovir exerted antiviral effects against adenovirus in vitro. We believe that this result is promising for prospective clinical studies on this subject. The effect of ganciclovir, one of the most promising drugs for the treatment of adenoviral conjunctivitis, could not be demonstrated in our study, and further studies are needed to elucidate possible resistance mechanisms in this regard. We observed that PVP-I and CHX are highly cytotoxic even at low concentrations and believe that their efficacy/sideeffect profiles should be evaluated together in future clinical studies. To our knowledge, this is the first study of CSA against adenovirus in vitro, and we observed that this drug was not effective below the cytotoxic concentrations. However, we still believe that our study has value as a guide for future studies.

* Ethics Committee of Cukurova University, Medical Faculty, Adana, Turkey Number of meetings: 87; number of decisions: 9.

\section{Declarations}

The authors declare that the manuscript has not been published previously and not under consideration for publication elsewhere.

Disclosure of potential conflicts of interest: None of the authors have any potential conflicts of interest to disclose

Funding: This study was supported by Cukurova University, Scientific Research Projects Unit, Project No: TTU-2019-12009.

Ethics approval: The study was compliant with the Declaration of Helsinki and additional approval was obtained from the Ethics Committee of Cukurova University, Medical Faculty, Adana, Turkey. (Number of meetings: 87 ; number of decisions: 9).

Author Contributions: All authors contributed to the study conception and design. Material preparation, data collection and analysis were performed by Gokhan Ozturk and Fugen Yarkin. The first draft of the 
manuscript was written by Aynura Sariyeva Aydamirov and all authors commented on previous versions of the manuscript. All authors read and approved the final manuscript.

Funding This study was supported by Cukurova University, Scientific Research Projects Unit. Project No: TTU-2019-12009

\section{Compliance with ethical standards}

Conflict of interest The authors declare they have no conflict of interest.

\section{References}

1. Ghebremedhin B (2014) Human adenovirus: Viral pathogen with increasing importance. Eur J Microbiol Immunol 4:26-33. https://doi.org/ 10.1556/EuJMI.4.2014.1.2

2. Meyer-Rusenberg B, Loderstadt U, Richard G, Kauffers PM, Gesser C (2011) Epidemic keratoconjunctivitis: The current situation and recommendations for prevention and treatment. Dtsch Arztebl Int 108:475-480. 10.3238/arztebl.2011.0475

3. Jernigan JA, Lowry BS, Hayden FG, Kyger SA, Conmay BP, Gröschel DH et al (1993) Adenovirus type 8 epidemic keratoconjunctivitis in an eye clinic: Risk factors and control. J Infect Dis 167:13071313. https://doi.org/ 10.1093/infdis/167.6.1307

4. Ariga T, Shimada Y, Shiratori K, Ohgami K, Yamazaki S, Tagawa Y et al (2005) Five New Genome Types of Adenovirus Type 37 Caused Epidemic Keratoconjunctivitis in Sapporo, Japan, for More Than 10 Years. J Clin Microbiol 43:726-732. https://doi.org/10.1128/JCM.43.2.726-732.2005

5. Adhikary AK, Ushijima H, Fujimoto T (2012) Human adenovirus type 8 genome typing. J Med Microbiol 61:1491-1503. https://doi.org/10.1099/jmm.0.044172-0

6. Adhikary AU, Banik U (2014) Human adenovirus type 8: The major agent of epidemic keratoconjunctivitis (EKC). J Clin Virol 61:477-486. https://doi.org/ 10.1016/j.jcv.2014.10.015

7. Baba M, Mori S, Shigeta S, De Clerq E (1987) Selective Inhibitory Effect of (S)-9-(3-Hydroxy-2Phosphonylmethoxypropyl) Adenine and 2'-NorCyclic GMP on Adenovirus Replication In Vitro. Antimicrob Agents Chemother 31:337-339. https://doi.org/10.1128/AAC.31.2.337

8. Hillenkamp J, Reinhard T, Ross RS et al (2001) Topical treatment of acute adenoviral keratoconjunctivitis with $0.2 \%$ cidofovir and $1 \%$ cyclosporine: a controlled clinical pilot study. Arch Ophthalmol 119:1487-1491. https://doi.org/ 10.1001/archopht.119.10.1487

9. McDonnell G, Russell AD (1999) Antiseptics and disinfectants: activity, action and resistance. Clin Microbiol Rev 12:147-179. https://doi.org/ 10.1128/CMR.12.1.147

10. Bailey A, Longson M (1972) Virucidal activity of chlorhexidine on strains of Herpesvirus hominis, poliovirus, and adenovirus. J Clin Pathol 25:76-78. https://doi.org/ 10.1136/jcp.25.1.76

11. Kinchington PR, Romanowski EG, Jerold Gordon Y (2005) Prospects for adenovirus antivirals. J Antimicrob Chemother 55:424-429. https://doi.org/10.1093/jac/dki057 
12. Trousdale MD, Goldschmidt PL, Nóbrega R (1994) Activity of Ganciclovir against human Adenovirus Type-5 infection in cell culture and cotton rat eyes. Cornea 13:435-439. https://doi.org/10.1097/00003226-199409000-00011

13. Yabiku ST, Yabiku MM, Bottos KM et al (2011) Ganciclovir $0.15 \%$ ophthalmic gel in the treatment of adenoviral keratoconjunctivitis. Arq Bras Oftalmol 74:417-421. https://doi.org/10.1590/s000427492011000600007

14. Monnerat N, Bossart W, Thiel MA (2006) Povidone-iodine for treatment of adenoviral conjunctivitis: an in vitro study. Klin Monbl Augenheilkd 223:349-352. https://doi.org/10.1055/s-2006-926633

15. Chigbu DI, Labib BA (2018) Pathogenesis and Management of Adenoviral Keratoconjunctivitis. Infect Drug Resist 11:981-993. https://doi.org/10.2147/IDR.S162669

16. Kawana R, Kitamura T, Nakagomi $O$ et al (1997) Inactivation of Human Viruses by Povidone-lodine in Comparison with Other Antiseptics. Dermatology 195:29-35. https://doi.org/10.1159/000246027

17. Sriwilaijaroen N, Wilairat $P$, Hiramatsu $\mathrm{H}$ et al (2009) Mechanisms of the action of povidone-iodine against human and avian influenza $A$ viruses: its effects on hemagglutination and sialidase activities. Virol J 6:124. https://doi.org/10.1186/1743-422X-6-124

18. Kunt Z, Yagmur M, Kandemir $\mathrm{H}$ et al (2002) In Vitro Efficacy of Chlorhexidine and a riboflavin/UVA Combination on Fungal Agents of Keratitis. Curr Eye Res 45:7-11. https://doi.org/10.1186/1743422X-6-124

19. Rahman MR, Johnson GJ, Husain R, Howlader SA, Minassian DC (1998) Randomised trial of $0.2 \%$ chlorhexidine gluconate and 2.5\% natamycin for fungal keratitis in Bangladesh. Br J Ophthalmol 82:919-925. https://doi.org/10.1136/bjo.82.8.919

20. Geffen N, Norman G, Kheradiya NS, Assia El (2009) Chlorhexidine Gluconate $0,002 \%$ as Adjunct to Primary Tratment for Corneal Bacterial Ulcers. Isr Med Assoc J 11:664-668

21. Shen Z, He H, Wu Y, Li J (2013) Cyclosporin a inhibits rotavirus replication and restores interferonbeta signaling pathway in vitro and in vivo. PLoS ONE 8:e71815. https://doi.org/10.1371/journal.pone.0071815

22. Asena L, Singar Ozdemir E, Burcu A et al (2017) Comparison of clinical outcome with different treatment regimens in acute adenoviral keratoconjunctivitis. Eye 31:781-787. https://doi.org/10.1038/eye.2017.4

23. Lin F, Young HA (2014) Interferons: Success in anti-viral immunotherapy. Cytokine Growth Factor Rev 25:369-376. https://doi.org/10.1016/j.cytogfr.2014.07.015

24. De Olviera CB, Stevenson D, LaBree L et al (1996) Evaluation of Cidofovir (HPMPC, GS-504) against adenovirus type 5 infection in vitro and in a New Zealand rabbit ocular model. Antiviral Res 31:165172. https://doi.org/10.1016/0166-3542(95)00962-0

25. Gordon YJ, Romanowski EG, Araullo-Cruz (1994) Topical HPMPC inhibits adenovirus type 5 in the New Zealand rabbit ocular replication model. Invest Ophthalmol Vis Sci 35:4135-4143

26. Woods G, Young A (1988) Use of A-549 Cells in a Clinical Virology Laboratory. J Clin Microbiol 26:1026-1028. https://doi.org/10.1128/jcm.26.5.1026-1028.1988 
27. Lipson S, Poshni IA, Ashley RL, Grady LJ, Ciamician Z, Teichberg S (1993) Presumptive identification of common adenovirus serotypes by the development of differential cytopathic effects in the human lung carcinoma (A549) cell culture. FEMS Microbiol Lett 113:175-182.

https://doi.org/10.1111/j.1574-6968.1993.tb06510.x

28. Affedt J, Rathod NG, Fernandez KB et al (2012) Ganciclovir in the Treatment of Ophthalmic Viral Infections - Case Reports. US Ophthalmic Review 5:100-104

29. Tunay ZO, Ozdemir O, Petricli IS (2015) Povidone iodine in the treatment of adenoviral conjunctivitis in infants. Cutan Ocul Toxicol 34:12-15. https://doi.org/10.3109/15569527.2014.888077

30. Wood A, Payne D (1998) The action of three antiseptics/disinfectants against enveloped and nonenveloped viruses. J Hosp Infect 38:283-295. https://doi.org/10.1016/s0195-6701(98)90077-9

31. Springthorpe V, Grenier J, Lloyd-Evans N, Sattar SA (1986) Chemical disinfection of human rotaviruses: Efficacy of commercially-available products in suspension tests. J Hyg 97:139-161. https://doi.org/10.1017/s0022172400064433

32. Vahlne A, Larsson PA, Horal $P$ et al (1992) Inhibition of herpes simplex virus production in vitro by cyclosporin A. Arch Virol 122:61-75. https://doi.org/10.1007/BF01321118

33. Sohn SY, Hearing P (2019) Adenoviral strategies to overcome innate cellular responses to infection. FEBS Lett 593:3484-3495. https://doi.org/10.1002/1873-3468.13680

\section{Figures}

\section{$\mathrm{CC}_{50}: 564 \pm 26 \mu \mathrm{M}$}
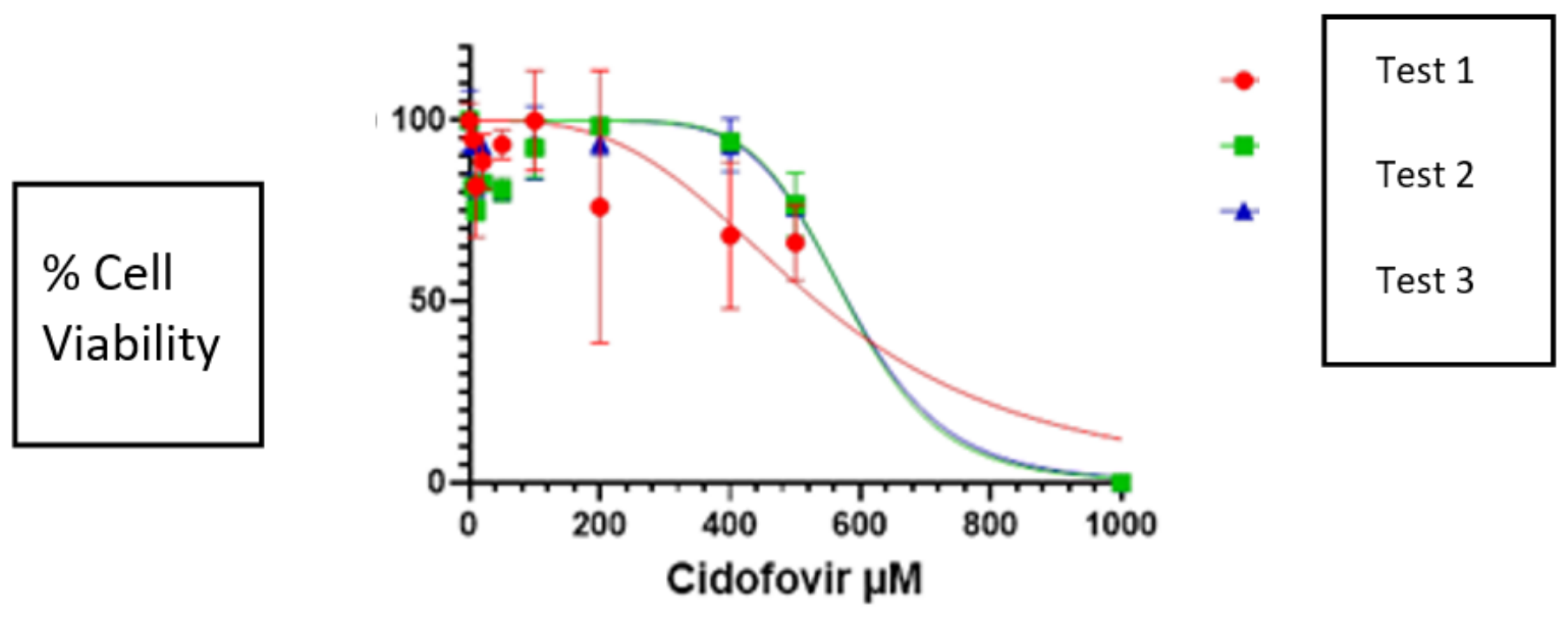

\section{Figure 1}

The $50 \%$ cytotoxic concentration $\left(\mathrm{CC}_{50}\right)$ value of cidofovir in A549 cells 


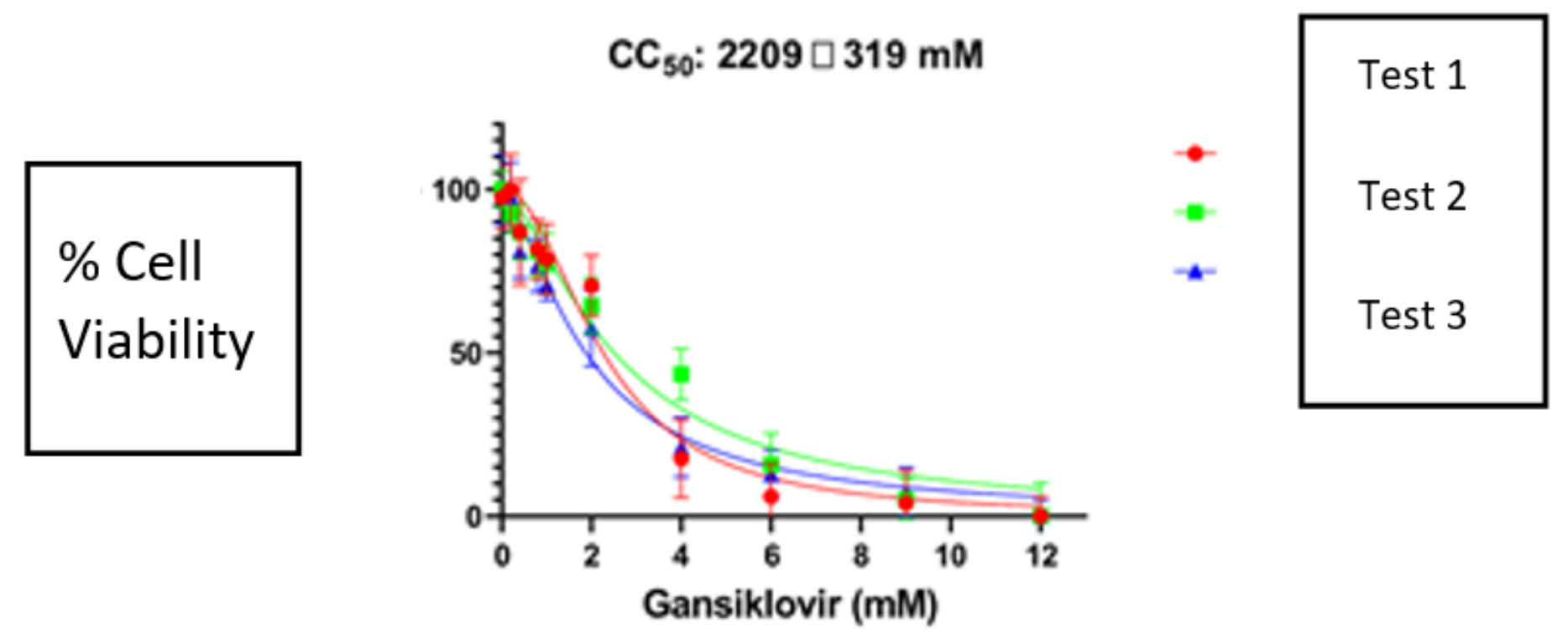

Figure 2

The $50 \%$ cytotoxic concentration $\left(\mathrm{CC}_{50}\right)$ value of ganciclovir in $\mathrm{A} 549$ cells

\section{$\mathrm{CC}_{50}: \% 0.5446 \pm 0.063$}
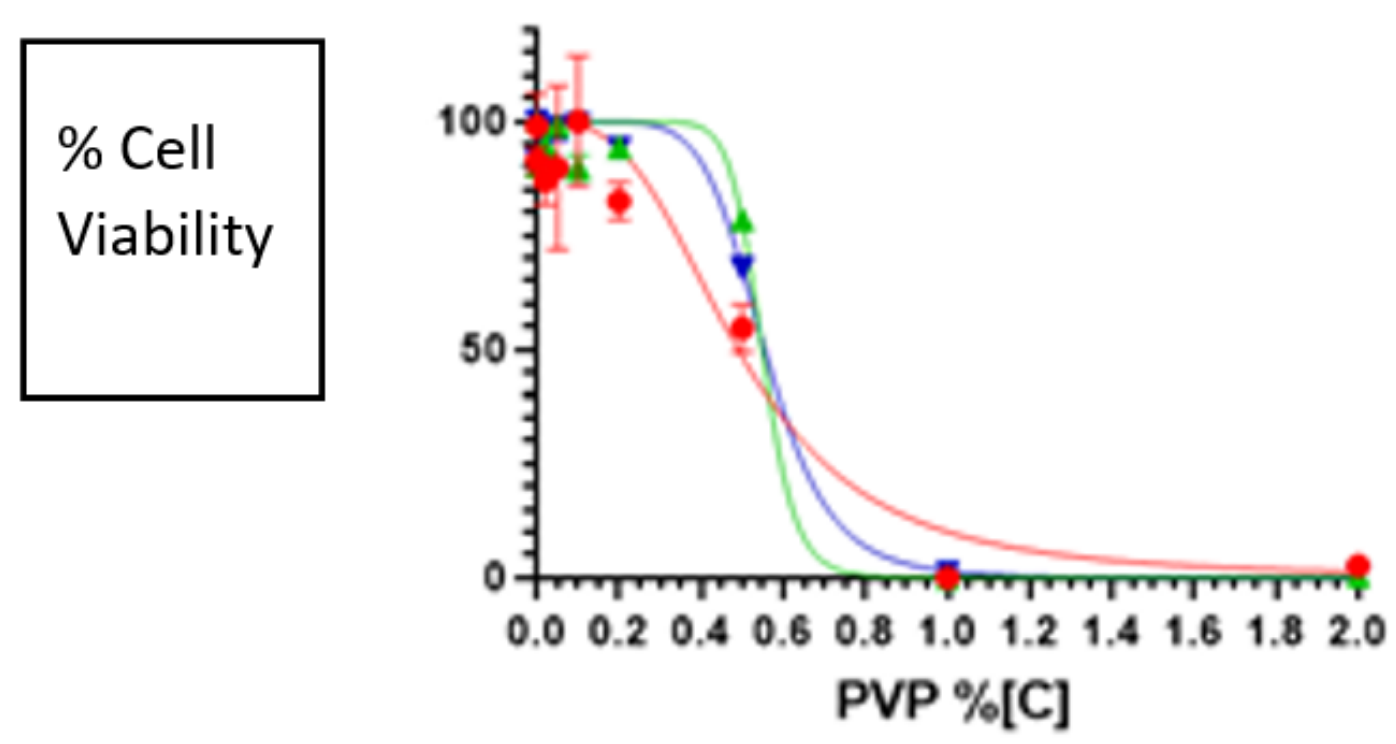

Test 1

Test 2

Test 3

Figure 3

The $50 \%$ cytotoxic concentration $\left(\mathrm{CC}_{50}\right)$ value of povidone iodine (PVP-1) in A549 cells 


\section{$\mathrm{CC}_{50}: \% 0.000589 \pm 0.0002$}

\begin{tabular}{|l|}
\hline$\%$ Cell \\
Viability \\
\hline
\end{tabular}

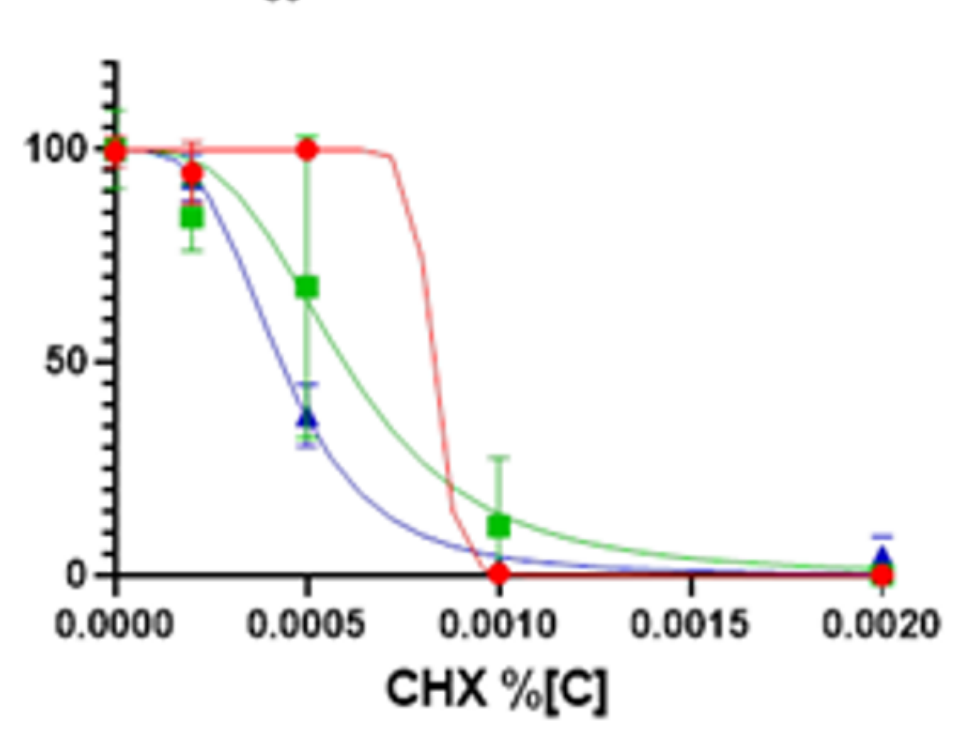

Test 1

Test 2

Test 3

\section{Figure 4}

The $50 \%$ cytotoxic concentration $\left(\mathrm{CC}_{50}\right)$ value of chlorhexidine $(\mathrm{CHX})$ in $\mathrm{A} 549$ cells

\begin{tabular}{|l|}
\hline$\%$ Cell \\
Viability \\
\hline
\end{tabular}

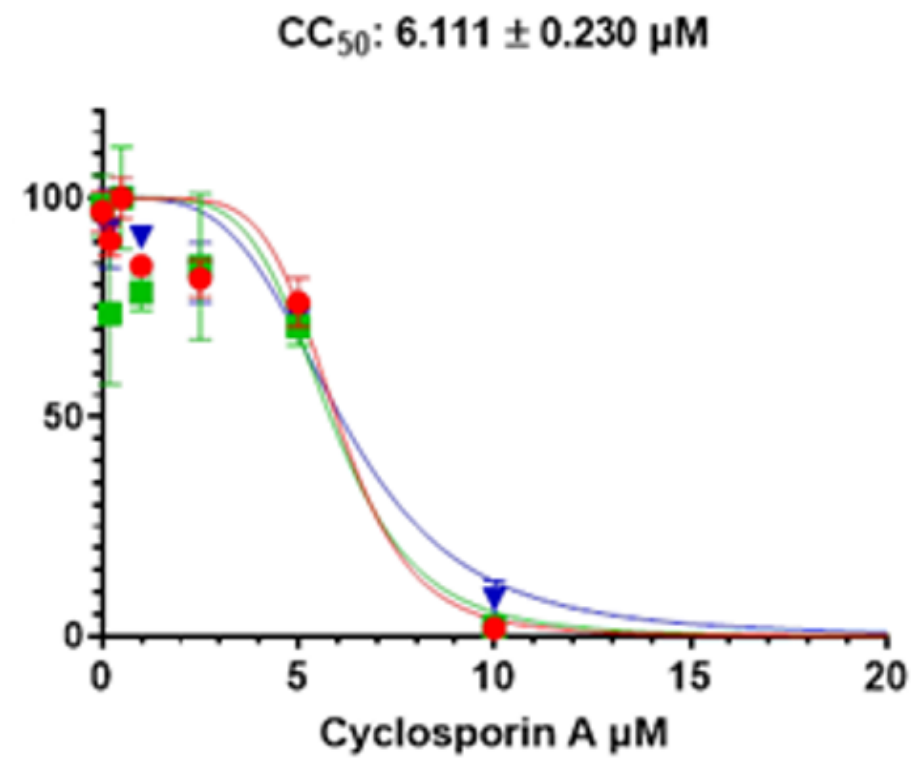

\begin{tabular}{|c|}
\hline Test 1 \\
\hline Test 2 \\
\hline Test 3 \\
\hline
\end{tabular}

Figure 5

The $50 \%$ cytotoxic concentration $\left(\mathrm{CC}_{50}\right)$ value of cyclosporine $\mathrm{A}(\mathrm{CSA})$ in $\mathrm{A} 549$ cells 


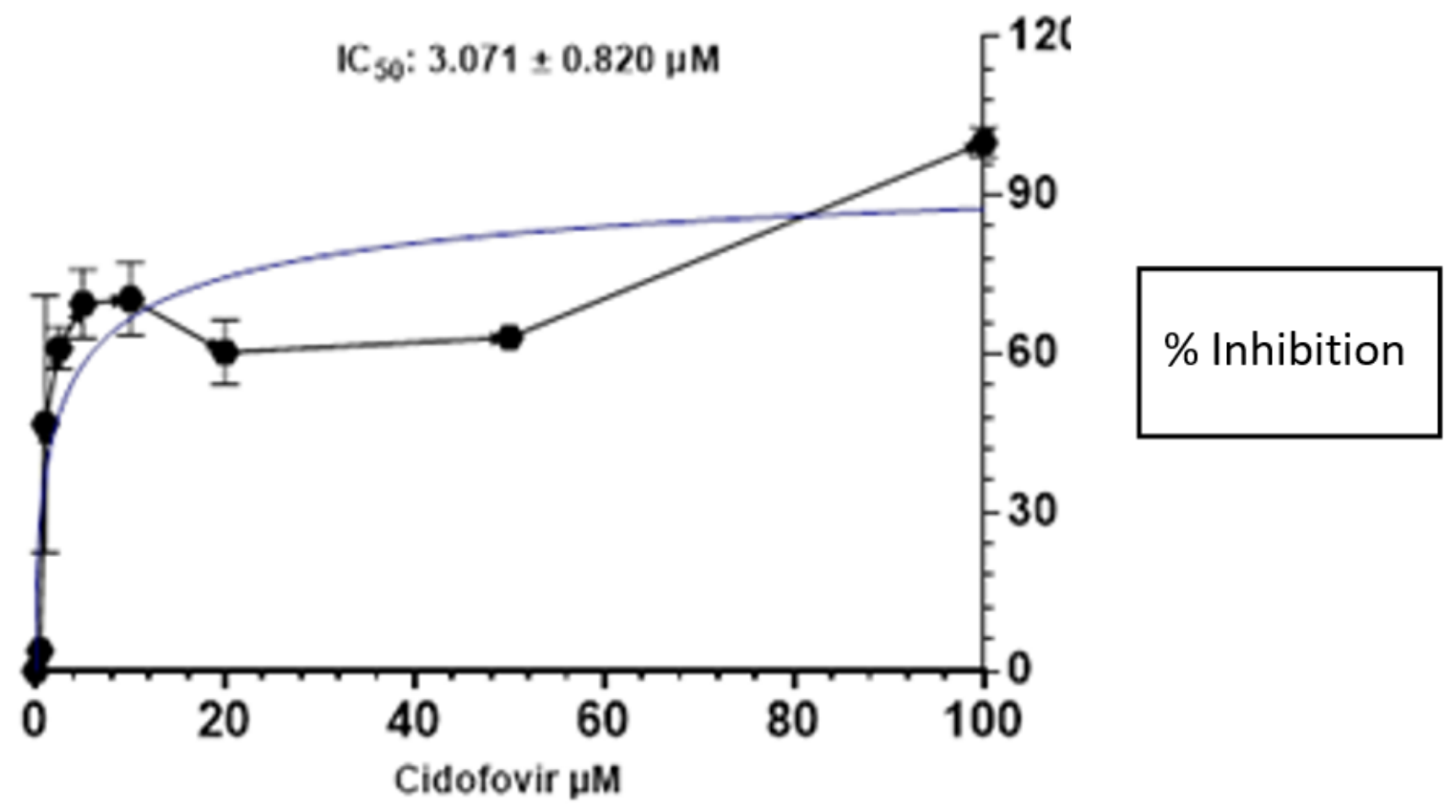

Figure 6

The $50 \%$ inhibitory concentration $\left(\mathrm{IC}_{50}\right)$ value of cidofovir in $\mathrm{A} 549$ cells 